\title{
The accumulation of rare-earth yttrium ions by Penicillium sp. ZD28
}

\author{
Weiying Wang ${ }^{1}$, Chenglong Xu ${ }^{1}$, Yiqiao Jin ${ }^{1}$, Zhibin Zhang ${ }^{1}$, Riming Yan ${ }^{1}$ and Du Zhu ${ }^{1}, 2^{*}$ (i)
}

\begin{abstract}
To obtained fungal resources with excellent tolerance and accumulation capacity to rare earth yttrium ions $\left(\mathrm{Y}^{3+}\right)$, rare earth ore samples were collected and used for microbial screening. A fungus hyper-resistant to $\mathrm{Y}^{3+}$ was obtained and the effects of the fungus in three physiological states (growth process, mycelial pellets with physiological activity and the fungus powder after being ground) on the $\mathrm{Y}^{3+}$ accumulation were investigated. The $\mathrm{Y}^{3+}$ resistant fungus was identified as Penicillium sp. ZD28, and its mycelium pellets (about $1 \mathrm{~mm}$ in diameter) showed poor ability to accumulate $\mathrm{Y}^{3+}$ with an adsorption capacity of less than $81 \mu \mathrm{mol} / \mathrm{g}$. However, the fungus was able to remove $99 \%$ of $\mathrm{Y}^{3+}$ during the growth process, at an initial concentration of less than $600 \mu \mathrm{M}$. Bioaccumulation of $Y$ was observed on the cell surface of the ZD28 strain by elemental mapping using scanning electron microscopy-energy dispersive X-ray spectroscopy. The adsorbent (the dry fungal powder) had a remarkable adsorption property for $\mathrm{Y}^{3+}$ that was greater than $455 \mu \mathrm{mol} / \mathrm{g}$ in conditions of $465 \mu \mathrm{M}<\left[\mathrm{Y}^{3+}\right]<6382 \mu \mathrm{M}$. Penicillium sp. ZD28 has major potential applications in the accumulation of yttrium group rare earth ions. This research has formed a theoretical foundation for the application of this biological method to extract rare earth ions in the mining and smelting of yttrium group rare earth elements.
\end{abstract}

Keywords: Rare earth yttrium ion, Penicillium sp. ZD28, Accumulation effect

Rare earth elements (REEs) comprise 17 elements in the periodic table, including 15 lanthanide elements, scandium (Sc) and yttrium (Y). Due to its unique physical and chemical properties, REEs are widely used in various fields of modern industry, particularly in many clean energy technologies and consumer products (Stone 2009; Alonso et al. 2012). In 2 decades, the price of REEs has been increasing, leading to the high prosperity in rare earth mining (Chen et al. 2013).

China has one of the most abundant REE resources in the world, with ion-adsorption heavy rare earth minerals accounting for two-thirds of China's rare earth resources which provides greater than $90 \%$ of the global REEs supply (Wang 2014). "Foot Cave", located in Longnan, Ganzhou city of Jiangxi province, is currently the

\footnotetext{
*Correspondence: zhudu12@163.com

${ }^{1}$ Key Laboratory of Protection and Utilization of Subtropical Plant Resources of Jiangxi Province, College of Life Sciences, Jiangxi Normal University, Nanchang 330022, China

Full list of author information is available at the end of the article
}

largest ion-adsorption type heavy rare earth deposits. It covers an area of $40 \mathrm{~km}^{2}$ and is the main heavy earth element raw materials supplier in China. Rare earth ions are adsorbed on the surface of clay minerals, such as montmorillonite, kaolinite and muscovite. The yttrium group is the main element in clay $\left(\sum \mathrm{Y}_{2} \mathrm{O}_{3} / \sum \mathrm{TR}_{2} \mathrm{O}_{3} \geq 90 \%\right)$ (Yang 2015). Five REEs (Tb, Dy, Eu, Nd, and Y) in particular have been highlighted by the U.S, because its critical to the development of 'clean' emerging energy technologies (Zhuang et al. 2015; US Department of Energy 2011). Huge market demand has led to a boom in yttrium-rich rare-earth mining. At present, in situ or pool leaching using ammonium sulphate solution is the main mining technology (Moldoveanu and Papangelakis 2012), however, this approach leads to serious environment problems, reflected in the production of large amounts of ammonia nitrogen waste-water (concentrations as high as $3500-4000 \mathrm{mg} / \mathrm{L}$ ) during the course of leaching and extraction. A large quantity of ammonia nitrogen infiltrates into soil, groundwater and surface
Springer Open (c) The Author(s) 2020. This article is licensed under a Creative Commons Attribution 4.0 International License, which permits use, sharing, adaptation, distribution and reproduction in any medium or format, as long as you give appropriate credit to the original author(s) and the source, provide a link to the Creative Commons licence, and indicate if changes were made. The images or other third party material in this article are included in the article's Creative Commons licence, unless indicated otherwise in a credit line to the material. If material is not included in the article's Creative Commons licence and your intended use is not permitted by statutory regulation or exceeds the permitted use, you will need to obtain permission directly from the copyright holder. To view a copy of this licence, visit http://creativeco mmons.org/licenses/by/4.0/. 
water along with rainfall. This results in a major excess of ammonia nitrogen in the water system causing a great threat to ecological security due to water eutrophication (Feng et al. 2017; Gao and Zhou 2011). Therefore, there is an urgent need to develop green extraction technology for applications in ion-adsorption rare earth mines (Xiao et al. 2015).

Microbial leaching technology is new metallurgical technology of mineral resources that is attracting increasing attention (Brierley and Brierley 2013; Kücüker et al. 2016). For ion-adsorption rare element mine, microbial mining is simpler as it involves biosorption (bioaccumulation). Microbially mediated surface adsorption (biosorption) represents a potentially cost-effective and eco-friendly approach for metal recovery ( $\mathrm{Li}$ and Tao 2015; Zhuang et al. 2015; Moriwaki and Yamamoto 2013). Bacteria exhibit high metal adsorption capacities because of their large specific surface area, small volume and abundance of cell surface functional groups (e.g., carboxylates and phosphates) with metal coordination functionality (Moriwaki and Yamamoto 2013). Moreover, fast reproduction rates can increase the advantages for applications in rare earth extraction processes (Tsuruta 2007; Mullen et al. 1989). Compared to bacteria, large-sized fungal mycelia are more advantageous in environmentally friendly green technology. Furthermore, fungi can secrete more extracellular polymers which can significantly increase the yield of biosorption (Das 2010).

Currently, investigations into the microbial accumulation of rare-earth ions have mainly focused on bacterial biomass adsorption. In these studies, prepared bacteria were used for rare earth adsorption. For example, the adsorption capacities of bacterial powder made from Pseudomonas aeruginosa to $\mathrm{La}^{3+}, \mathrm{Eu}^{3+}$ and $\mathrm{Yb}^{3+}$ were 397, 290 and $326 \mu \mathrm{mol} / \mathrm{g}$, respectively (Texier et al. 1999). However, metal ion accumulation during the growth of fungi has greater potential according to the studies by Horiike who found that the fungus Penidiella sp. T9, could efficiently accumulate dysprosium ions $\left(\mathrm{Dy}^{3+}\right)$. They also showed that the Dy content in the cell pellet of the T9 strain was $910 \mu \mathrm{g} / \mathrm{mg}$ of dry cells (Horiike and Yamashita 2015), indicating that the accumulation capacity of $\mathrm{Dy}^{3+}$ was as high as $5400 \mu \mathrm{mol} / \mathrm{g}$, which is significantly superior to that of $P$. aeruginosa. However, there are very few reports on adsorption of yttrium group rareearth ions by fungi, which greatly hinders the application of biological methods in extraction and recovery of yttrium from "Foot Cave" mines and other ion-adsorption type heavy rare-earth deposits in the south of China.

In this study, soil samples were collected from the "Foot Cave" mine, which is a typical yttrium-rich rare earth ore, and a fungus with excellent tolerance and accumulation ability of $\mathrm{Y}^{3+}$ could be obtained by strain screening. The ability of the fungus in three physiological states (growth process, the mycelial pellets with physiological activity and the dry fungal powder after being ground) to accumulate yttrium was investigated. This study established a basic theory for the application of rare earth ion accumulation using fungi in ion-adsorption type REEs exploiting and provides a new concept for alleviating ecological destruction and environmental pollution from mining.

\section{Materials and methods}

\section{Collection of soil from the "Foot Cave" and analysis of rare earth ions in soil samples}

Early spring is the most suitable season for microbial reproduction. Topsoil was collected from the "Foot Cave" rare earth mine, from nine sampling points across

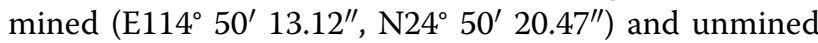
sites (E114 50' 12.67", N24 50' 02.21") in April. Three samples were taken from each site, and a total of 27 soil samples were taken back to the lab within $12 \mathrm{~h}$. The samples were divided into two parts: one sample was placed at $4{ }^{\circ} \mathrm{C}$ for microbial screening, the other sample was airdried and passed through a 200 mesh sieve after grinding and mixing, and then sent to the ALS Minerals laboratory (Guangzhou, China) to determine the content of REEs by ICP-MS/MS.

\section{Isolation of $\mathrm{Y}^{3+}$-tolerant fungi}

Soil samples obtained from the REE mines were mixed together ( $0.5 \mathrm{~g}$ per sample) for the screening experiment. Then, $13.5 \mathrm{~g}$ of the mixed sample was transferred into enrichment medium (Potato Dextrose Broth, PDB). The mixtures were incubated at $28{ }^{\circ} \mathrm{C}$ and stirring at $120 \mathrm{rpm}$ overnight. $10 \mathrm{~mL}$ of the culture was then injected into a fresh enrichment medium, followed by incubation at $28{ }^{\circ} \mathrm{C}$ and stirring at $120 \mathrm{rpm}$ overnight. Then, the culture was subjected to separation using a PDA agar plate to obtain single clones. A total of eleven different strains of filamentous fungi with different appearances were obtained. Spores were collected and spore suspensions were prepared for the $\mathrm{Y}^{3+}$-tolerance assay.

PDA plates with different concentrations of $\mathrm{Y}^{3+}$ were prepared as follows: $200 \mathrm{~g}$ of small pieces of fresh potato were boiled in $800 \mathrm{~mL}$ of deionized water until they became fluffy mashed potato. $20 \mathrm{~g}$ of glucose was added to the water whilst hot. The volume was fixed to $1 \mathrm{~L}$ after filtration using a gauze. The prepared medium was divided into five equal parts, and placed in five $250 \mathrm{~mL}$ flasks. $1.5 \%$ agar was added before sterilization at $121^{\circ} \mathrm{C}$ for $15 \mathrm{~min}$. The PDA medium was cooled to about $55^{\circ} \mathrm{C}$, different volumes of $\mathrm{Y}^{3+}$ stock solutions (sterilized by $0.22 \mu \mathrm{m}$ filtration membrane) were added, shaken and poured into petri dishes for use in fungal culture after solidification. The final concentration of $\mathrm{Y}^{3+}$ was 10,200 , 
400 and $800 \mathrm{mg} / \mathrm{L}$, respectively. The eleven filamentous fungal spores $(2 \mu \mathrm{L})$ were inoculated on the PDA plates with different concentrations of $\mathrm{Y}^{3+}$. Growth and morphological changes were observed after being cultured at $28^{\circ} \mathrm{C}$ for $60 \mathrm{~h}$.

\section{Sequencing of the 5.8S rRNA gene}

Strain number 1 was cultured in PDB for 3 days. Cultured cells were harvested by centrifugation $(12,000 \mathrm{~g}$, $5 \mathrm{~min}, 4{ }^{\circ} \mathrm{C}$ ), and washed twice in sterile saline. Genomic DNA was extracted from the disrupted cells according to Murmur's method (Marmur 1961). The 5.8S rRNA gene fragments were amplified from the extracted genomic DNA by PCR using PrimeSTAR ${ }^{\circledR}$ Max DNA Polymerase (TaKaRa Bio Inc., Shiga, Japan) and primers ITS1 (5'-TCCGTAGGTGAACCTGCGG-3') and ITS4 (5'TCCTCCGCTTATTGATATGC-3') (Gang et al. 2015). The PCR conditions were as follows: an initial denaturation step at $98{ }^{\circ} \mathrm{C}$ for $5 \mathrm{~min}$, followed by 30 cycles of $98{ }^{\circ} \mathrm{C}$ for $10 \mathrm{~s}$, annealing at $57^{\circ} \mathrm{C}$ for $5 \mathrm{~s}$, and elongation at $72{ }^{\circ} \mathrm{C}$ for $1 \mathrm{~min}$. The reactions were carried out in a Mastercycler thermal cycler (Eppendorf Co., Ltd., Tokyo, Japan). The PCR products were used as templates for direct nucleotide sequencing. The sequencing was performed by Sangon Biotech (Shanghai) Co., Ltd. The generated sequences were compared to other fungal RNA sequences in the GenBank database using BLAST (http://blast.ncbi.nlm.nih.gov/Blast.cgi) (Altschul et al. 1990). The isolated sequences and the GenBank sequences were aligned using Clustal W. A phylogenetic tree of the aligned sequence data was generated using Molecular Evolutionary Genetics Analysis (MEGA5.0) (Tamura et al. 2011), and the neighbor-joining method (NJ) (Saitou and Nei 1987). The percentages of replicate trees in which the associated taxa clustered together in the bootstrap test (1000 replicates) are shown next to the branches (Felsenstein 1985). The evolutionary distances were calculated using the maximum composite likelihood method (Tamura et al. 2004), and shown as the number of base substitutions per site.

\section{Nucleotide sequence accession number}

The sequence determined in this study was deposited in the DNA Data Bank of USA (https://www.ncbi.nlm.nih. gov/nuccore) under accession number MN503307.

\section{Interaction between yttrium and Penicillium sp. ZD28 during the growth process}

The interaction between yttrium and Penicillium sp. ZD28 during the growth process was determined under culture condition using Czapek's medium. Yttrium hydroxide precipitation can occur under conditions of $\mathrm{pH}>5$ (Tsuruta 2007), and some precipitation containing yttrium were produced with the increasing of $\mathrm{Y}^{3+}$ concentration. According to our preliminary experimental results, the initial $\mathrm{pH}$ of the medium was adjusted to 3.0, and so no precipitation would occur when the concentration of $\mathrm{Y}^{3+}$ was less than $600 \mu \mathrm{M}$. Czapek's medium $(\mathrm{pH}$ 3.0) was sterilized at $115^{\circ} \mathrm{C}$ for $30 \mathrm{~min}$. Different volumes of $\mathrm{Y}^{3+}$ stock solutions $(0.5 \mathrm{M}$, sterilized by $0.22 \mu \mathrm{m}$ filtration membrane) were added to the medium after cooling. The spore suspension $\left(10^{8} / \mathrm{mL}\right)$ was inoculated and cultured at $28{ }^{\circ} \mathrm{C}$ with stirring at $120 \mathrm{rpm}$ for 3 days. In the control samples, the spore suspension was replaced by $1 \mathrm{~mL}$ of sterile water. The experiment was repeated four times in each group. At the end of culture period, the supernatant and mycelium were separated by suction filtration. The $\mathrm{Y}^{3+}$ concentration in the supernatant from the groups with and without fungal inoculation was measured, and the difference between them is the accumulation of $\mathrm{Y}^{3+}$ concentration by the growing fungus. The mycelium was dried to a constant weight at $50^{\circ} \mathrm{C}$.

After culturing at the different concentrations of $\mathrm{Y}^{3+}$, the cultures in the flask were poured into petri dishes to observe the surface morphology changes of Penicillium sp. ZD28. The feather-like mycelium in group with the highest $\mathrm{Y}^{3+}$ concentration were fixed for $1 \mathrm{~h}$ at room temperature in $2.5 \%$ glutaraldehyde containing $\mathrm{Y}^{3+}$ at a concentration approximately equal to the initial concentration in medium, and the cells were then washed free of glutaraldehyde with $\mathrm{Y}^{3+}$ solution (Mullen et al. 1989). The cell pellets were taken into coverslip, spray-gold after air-dry, then observed by scanning electron microscopy (SEM) (S-3400 N; Hitachi High-Technologies Corp., Tokyo, Japan) operated at $30 \mathrm{kV}$. Energy-dispersive X-ray spectroscopy (EDX) (Quantax70; Bruker AXS Microanalysis $\mathrm{GmbH}$, Karlsruhe, $\mathrm{DE}$ ) was used to acquire the $\mathrm{X}$-ray spectra and map the elements.

At the same time, Czapek's medium solid plates with the same concentration gradient of $\mathrm{Y}^{3+}$ as the liquid medium were prepared. $2 \mu \mathrm{L}$ of spore suspension was added to the plates and a cover slide inserted obliquely near the fungus. The mycelium and spore morphology on the cover glass were observed by SEM after 3 days of culture.

\section{Accumulation of $\mathrm{Y}^{3+}$ by the mycelium pellet and the dry fungal powder}

Preparation of the mycelium pellet: $100 \mathrm{~mL}$ of PDB medium was placed in $250 \mathrm{~mL}$ flask, and sterilized at $121{ }^{\circ} \mathrm{C}$ for $15 \mathrm{~min} .1 \mathrm{~mL}$ of spore suspension with a concentration of $10^{8} / \mathrm{mL}$ was inoculated and cultured at $28{ }^{\circ} \mathrm{C}$ and stirred at $150 \mathrm{rpm}$ for 3 days. The mycelium pellet was obtained by suction filtration with filter paper, and used for yttrium ion adsorption, immediately after washing three times in deionized water. 
Preparation of the dry fungal powder: the mycelium was obtained using the same method described above, and then dried at $50{ }^{\circ} \mathrm{C}$ to a constant weight. The fungal powder was used for yttrium ion adsorption after grinding through a 100 mesh.

Accumulation of yttrium ions by the above two adsorbents: The appropriate amount of mycelium pellets could be dried at $50{ }^{\circ} \mathrm{C}$ to a constant weight, and the water content was calculated to be $13.35( \pm 0.50) \% .11 .54( \pm 0.05)$ $\mathrm{mg}$ of the pellets (equal to $10 \mathrm{mg}$ of dry fugal powder) and $10( \pm 0.05) \mathrm{mg}$ of the fungal powder were put into a $15 \mathrm{~mL}$ centrifuge tube. $10 \mathrm{~mL}$ of yttrium ion solution at different concentrations (about from 0.5 to $8.0 \mathrm{mM}$ ) was added and the $\mathrm{pH}$ adjusted to 5.0 with $6 \mathrm{M}$ hydrochloric acid. The above reaction was repeated three times in each group, and the supernatant was obtained by centrifuging at $6000 \mathrm{rpm}$ for $5 \mathrm{~min}$ after the equilibrium reaction for $6 \mathrm{~h}$ in a tube oscillator (Qilinbeier KB5010, Haimen, China) at room temperature. The $\mathrm{Y}^{3+}$ concentration in the supernatant was determined, which is denoted by $\mathrm{C}_{\mathrm{e}}$. The concentrations form the different prepared yttrium ion solutions were determined, which is denoted by $C_{0}$.

\section{Determination of $\mathrm{Y}^{3+}$ concentrations}

ICP-MS/MS method: High concentrations of yttrium ions can cause precipitation formation in Czapek's medium and so the accumulation of $\mathrm{Y}^{3+}$ by the growing fungus must be carried out in relatively low concentrations of yttrium ion. However, the concentration of yttrium ions was lower than the detection limit of the chemical method. Yttrium ion accumulation during growth of the fungus was detected using an ICP-MS/MS method (Agilent, 8900, USA). Yttrium concentrations of $0,5,10,15,20 \mathrm{ppb}$ were used as a standard curve.

Arsenazo III colorimetric method (Hogendoorn et al. 2018): $\mathrm{Y}^{3+}$ adsorption by the mycelium pellets and the dry fungal powder was determined by the Arsenazo III colorimetric method. The reaction system was as follows: $1 \mathrm{~mL}$ of citric acid/phosphate buffer ( $\mathrm{pH} 2.8$ ), $980 \mu \mathrm{L}$ of the sample and $20 \mu \mathrm{L}$ of $1 \mathrm{mM}$ Arsenazo III. A UV754N spectrophotometer (Youke, Shanghai, China) was used to measure optical density at $650 \mathrm{~nm}$. Yttrium concentrations of $0.5,1,5$ and $10 \mathrm{mM}$ were used to generate a standard curve.

\section{Results}

\section{Content of rare earth element in ore samples}

The content of rare earth ions in the soil samples showed very difference in content of light rare earth elements (LREEs) and heavy rare earth element (HREEs). Our results showed that HREEs are more abundant than LREEs both in exploited (sample 1-5) and unexploited (sample 6-9) soils. There was no significant difference in
LREEs content between in the exploited and unexploited soil. However, the content of HREEs in the unexploited samples was around an order of magnitude higher than that in the exploited soils. It is worth highlighting that the $\mathrm{Y}^{3+}$ content was highest in unexploited soil (surface soil) which reached up to an average of $1323 \mathrm{mg} / \mathrm{kg}$ (Table 1 ).

\section{Isolation of $\mathrm{Y}^{3+}$-tolerant microorganisms}

Eleven fungi strains were obtained by preliminary screening. The eleven isolates were inoculated on PDA plates with different concentrations of $\mathrm{Y}^{3+}$. The morphology and size of colonies were different under different concentrations of $\mathrm{Y}^{3+}$ over a cultivation period of 3 days (Fig. 1). The colonies gradually became smaller with increasing $\mathrm{Y}^{3+}$ concentration. Strains numbers 1 to 4 were able to live at $800 \mathrm{mg} / \mathrm{L} \mathrm{Y}^{3+}$, indicating a high tolerance to $\mathrm{Y}^{3+}$. Amongst these strains, strain number 1 had the largest tolerance to $\mathrm{Y}^{3+}$. The colony size gradually decreased with the increase of $\mathrm{Y}^{3+}$ concentration. However, the mycelium micromorphology and spore production were not affected, showing that the fungus had a high tolerance to $\mathrm{Y}^{3+}$. Therefore, strain number 1 was used as the target strain in this study. Also, the highest tolerated concentration of $\mathrm{Y}^{3+}$ in fungus samples 7 and 8 was $200 \mathrm{mg} / \mathrm{L}$, and that of strains number 5 and 6 was $100 \mathrm{mg} / \mathrm{L}$ under solid culture conditions. A partial nucleotide sequence (554 bases) of the ITS1/ITS4 rRNA gene of the strain number 1 was determined and compared with sequences in GenBank using BLAST. The nucleotide sequence was found to have $99.8 \%$ homology with $P$. ochrochloron YXsoil4 (MH128152.1), and 99.1\% homology with P. ochrochloron SWUKD4.1850 (KX346178.1). These fungi are classified as class Plectomycetes, order Onygenales, family Eurotiaceae, genus Penicillium. The phylogenetic tree (Fig. 2) shows high similarity between strain number 1 and the P. ochrochloron. Therefore, strain number 1 was named Penicillium sp. ZD28 together with the microscopic characteristics. The fungus has been deposited in the China Typical Model Cultivation Center with preservation number CCTCC M 2019865.

\section{Interactions between Penicillium sp. ZD28 and $\mathrm{Y}^{3+}$}

Yttrium has a major influence on the morphology of Penicillium sp. ZD28 under liquid culture conditions: yttrium at low concentration promotes an increase in fuangal biomass whilst yttrium at high concentration inhibits biomass. When $\mathrm{Y}^{3+}$ was added into the Czapek's medium at concentration of $73.71 \mu \mathrm{M} \mathrm{Y}^{3+}$, the dry weight of mycelium pellets was significantly higher than that of in the absence of $\mathrm{Y}^{3+}$, but the shape of the mycelium pellets remained unchanged. When the concentration of $\mathrm{Y}^{3+}$ reached $461.57 \mu \mathrm{M}$, mycelium pellets were small and irregular in shape. The surfaces of the 
Table 1 Light and heavy rare earth element content in soil samples

\begin{tabular}{|c|c|c|c|c|c|c|c|c|c|}
\hline \multirow[t]{2}{*}{ Soil samples ${ }^{a}$} & \multicolumn{9}{|c|}{ Content of the light REEs (mg/kg) } \\
\hline & \multicolumn{2}{|l|}{ La } & $\mathrm{Ce}$ & \multicolumn{2}{|l|}{$\operatorname{Pr}$} & $\mathrm{Nd}$ & \multicolumn{2}{|l|}{ Sm } & $\mathrm{Eu}$ \\
\hline 1 & \multicolumn{2}{|c|}{$20.4 \pm 1.5$} & $42.7 \pm 10$ & \multicolumn{2}{|c|}{$8.70 \pm 2.1$} & $44.7 \pm 3.5$ & \multicolumn{2}{|c|}{$33.6 \pm 11.2$} & $0.13 \pm 1.5$ \\
\hline 2 & \multicolumn{2}{|c|}{$1.3 \pm 0.3$} & $29.5 \pm 5.0$ & \multicolumn{2}{|c|}{$0.94 \pm 0.2$} & $5.2 \pm 1.5$ & \multicolumn{2}{|c|}{$6.06 \pm 2.0$} & $0.03 \pm 0.01$ \\
\hline 3 & \multicolumn{2}{|c|}{$14.7 \pm 3.9$} & $28.5 \pm 1.2$ & \multicolumn{2}{|c|}{$4.58 \pm 1.5$} & $20.2 \pm 5.2$ & \multicolumn{2}{|c|}{$5.10 \pm 1.4$} & $1.85 \pm 1.5$ \\
\hline 4 & \multicolumn{2}{|c|}{$111.0 \pm 8$} & $98.6 \pm 6.0$ & \multicolumn{2}{|c|}{$30.1 \pm 2.6$} & $118.5 \pm 51$ & \multicolumn{2}{|c|}{$24.4 \pm 1.8$} & $6.03 \pm 1.2$ \\
\hline 5 & \multicolumn{2}{|c|}{$19.8 \pm 2.3$} & $50.1 \pm 3.2$ & \multicolumn{2}{|c|}{$8.89 \pm 1.5$} & $44.2 \pm 5.6$ & \multicolumn{2}{|c|}{$32.8 \pm 11.0$} & $0.20 \pm 0.1$ \\
\hline 6 & \multicolumn{2}{|c|}{$20.8 \pm 1.5$} & $40.1 \pm 6.2$ & \multicolumn{2}{|c|}{$8.52 \pm 2.1$} & $47.7 \pm 2.9$ & \multicolumn{2}{|c|}{$40.4 \pm 10.2$} & $0.58 \pm 0.12$ \\
\hline 7 & \multicolumn{2}{|c|}{$20.8 \pm 5$} & $43.5 \pm 14.1$ & \multicolumn{2}{|c|}{$8.46 \pm 1.5$} & $46.0 \pm 11.2$ & \multicolumn{2}{|c|}{$39.8 \pm 5.3$} & $0.49 \pm 0.23$ \\
\hline 8 & \multicolumn{2}{|c|}{$16.1 \pm 3.2$} & $31.1 \pm 2.3$ & \multicolumn{2}{|c|}{$6.77 \pm 1.1$} & $37.8 \pm 9.0$ & \multicolumn{2}{|c|}{$33.3 \pm 5.0$} & $0.45 \pm 0.33$ \\
\hline 9 & \multicolumn{2}{|c|}{$20.5 \pm 2.0$} & $34.7 \pm 10.1$ & \multicolumn{2}{|c|}{$8.19 \pm 3.9$} & $45.5 \pm 5.1$ & \multicolumn{2}{|c|}{$41.1 \pm 11.2$} & $0.52 \pm 0.12$ \\
\hline \multirow[t]{2}{*}{ Soil samples ${ }^{a}$} & Content of $t$ & e heavy REE & (mg/kg) & & & & & & \\
\hline & Gd & $\mathrm{Tb}$ & Dy & Ho & $\mathrm{Er}$ & $\mathrm{Tm}$ & $\mathrm{Yb}$ & Lu & $\mathrm{Y}$ \\
\hline 1 & $61.6 \pm 11.0$ & $12.45 \pm 2.1$ & $88.3 \pm 11.2$ & $18.95 \pm 2.1$ & $58.7 \pm 2.0$ & $8.43 \pm 5.1$ & $60.0 \pm 21.5$ & $9.40 \pm 2.1$ & $624 \pm 101.0$ \\
\hline 2 & $13.60 \pm 8.5$ & $3.66 \pm 1.5$ & $30.7 \pm 10.2$ & $7.87 \pm 1.5$ & $27.3 \pm 1.6$ & $4.90 \pm 2.0$ & $39.1 \pm 3.6$ & $6.46 \pm 1.5$ & $173.5 \pm 89.2$ \\
\hline 3 & $6.31 \pm 1.5$ & $0.95 \pm 0.2$ & $6.14 \pm 1.2$ & $1.25 \pm 0.6$ & $3.47 \pm 1.8$ & $0.45 \pm 0.23$ & $2.92 \pm 2.1$ & $0.43 \pm 0.2$ & $36.3 \pm 10.0$ \\
\hline 4 & $22.1 \pm 3.5$ & $2.96 \pm 0.3$ & $16.70 \pm 6.2$ & $3.31 \pm 1.2$ & $8.36 \pm 2.3$ & $1.06 \pm 0.56$ & $6.68 \pm 0.56$ & $1.02 \pm 0.2$ & $84.5 \pm 12.3$ \\
\hline 5 & $59.7 \pm 12.3$ & $13.60 \pm 2.3$ & $100.5 \pm 20.1$ & $22.7 \pm 2.3$ & $73.9 \pm 21.0$ & $11.70 \pm 2.3$ & $85.6 \pm 18.2$ & $13.40 \pm 1.8$ & $633 \pm 80.7$ \\
\hline 6 & $108.5 \pm 20.0$ & $21.6 \pm 4.2$ & $153.5 \pm 20.0$ & $35.3 \pm 12.4$ & $109.5 \pm 36.8$ & $15.75 \pm 6.5$ & $101.5 \pm 25.6$ & $16.65 \pm 8.3$ & $1415 \pm 500.1$ \\
\hline 7 & $105.0 \pm 18.0$ & $21.1 \pm 5.2$ & $153.5 \pm 18.3$ & $35.0 \pm 14.2$ & $107.5 \pm 50.2$ & $14.90 \pm 4.5$ & $100.0 \pm 35.1$ & $16.25 \pm 4.0$ & $1405 \pm 436.1$ \\
\hline 8 & $87.9 \pm 2.3$ & $17.40 \pm 3.9$ & $125.5 \pm 17.2$ & $28.8 \pm 10.1$ & $88.7 \pm 12.5$ & $12.60 \pm 7.2$ & $85.7 \pm 25.3$ & $14.00 \pm 2.9$ & $1095 \pm 221.0$ \\
\hline 9 & $108.5 \pm 14.2$ & $21.8 \pm 4.8$ & $156.0 \pm 26.3$ & $35.1 \pm 9.8$ & $107.0 \pm 41.2$ & $14.75 \pm 6.3$ & $97.6 \pm 38.1$ & $15.65 \pm 5.6$ & $1380 \pm 400.1$ \\
\hline
\end{tabular}

a Samples 1-5 were from the mined spot, where the soil is high in quartz and gray-white in color. Samples 6-9 were obtained from the unmined spot, where the soil is red topsoil after removing withered leaves

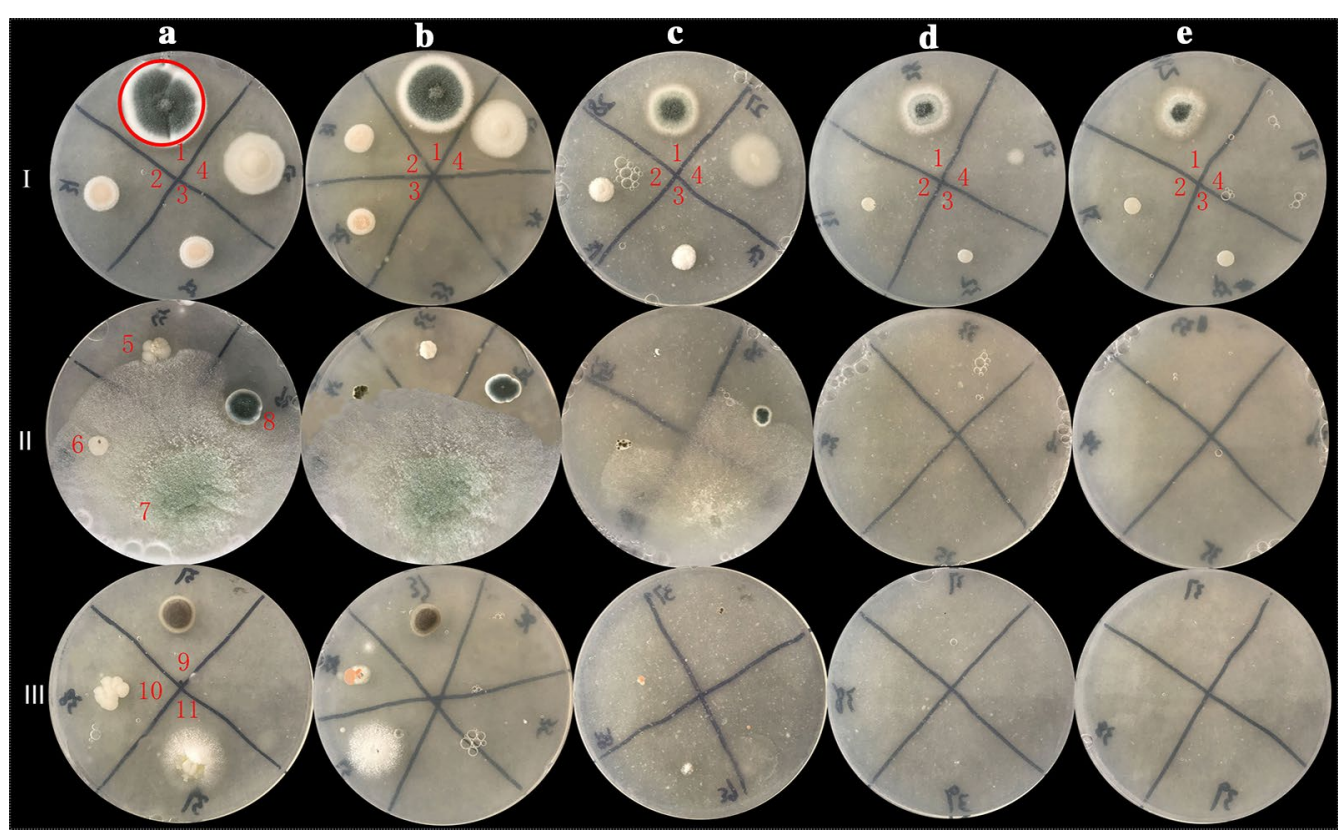

Fig. 1 Effects of different concentrations of $\mathrm{Y}^{3+}$ on fungal growth. The concentration of $\mathrm{Y}^{3+}$ in column of a-e were 10, 100, 200, 400 and 800 mg/L, respectively; the line I, II and III contain strains number 1-4,5-8,9-11, respectively. The strain number 1 in red circle is the target fungus, identified Penicillium sp. ZD28 


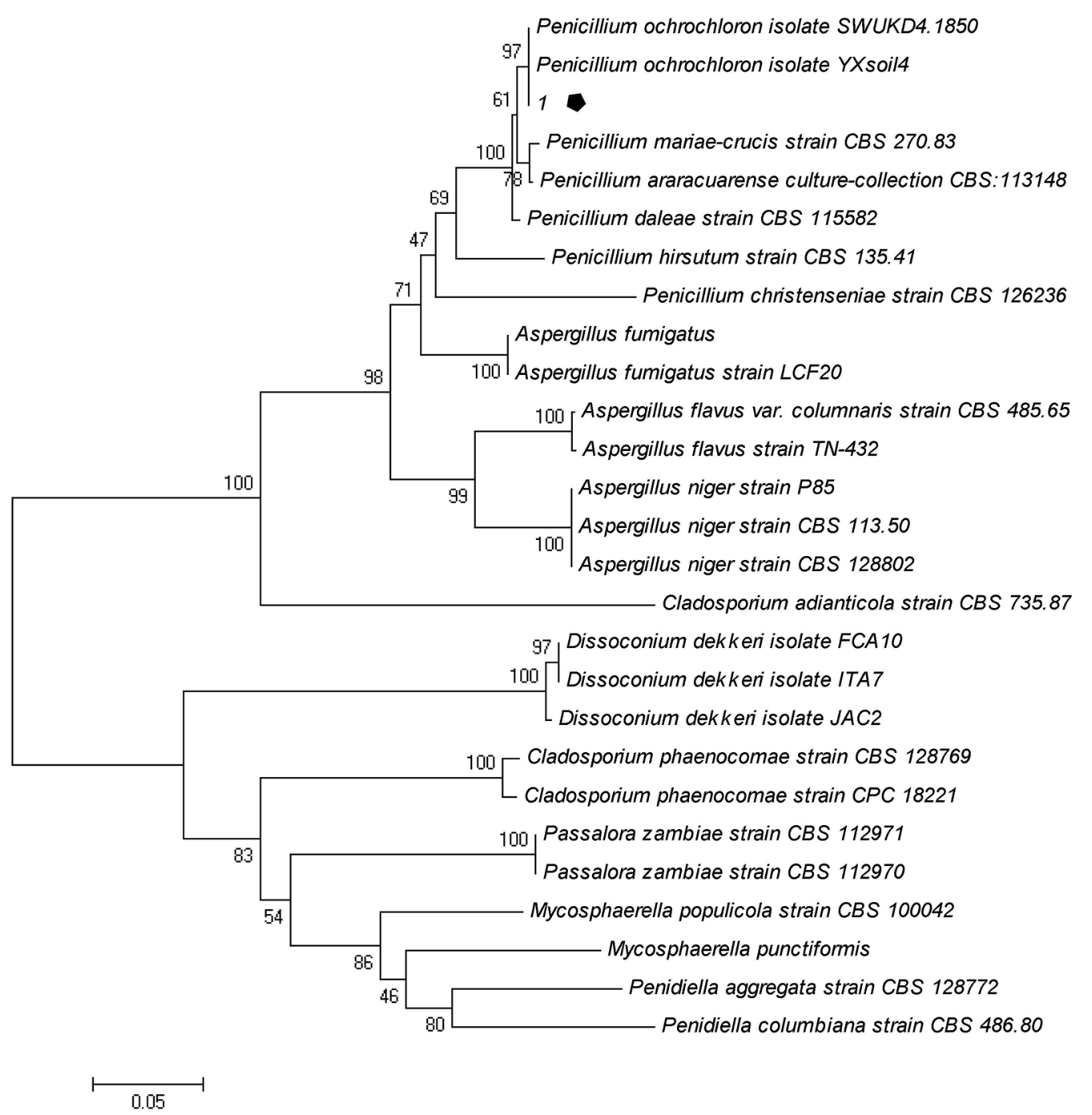

Fig. 2 Phylogenetic tree inferred from the 5.8S-ITS1/ITS4 rRNA gene sequences of Penicillium and Aspergillus

mycelium pellets were mostly radial and the dry weight of mycelium reached a maximum at this concentration (Fig. 4). When the concentration of $\mathrm{Y}^{3+}$ continued to rise to $580.67 \mu \mathrm{M}$, the shape of pellets became extremely irregular and seems to be feather-like. At this time, the dry weight of the mycelium decreased, but it was still higher in the absence of $\mathrm{Y}^{3+}$. These data indicated that $\mathrm{Y}^{3+}$ could promote the growth of mycelia across a certain concentration range, and yttrium at high concentration is toxic to the fungus. However, $\mathrm{Y}^{3+}$ had no effect on the micro-morphology and spore formation of Penicillium sp. ZD28 as observed with SEM (Fig. 3). In addition, there was no significant difference in $\mathrm{pH}$ between the groups at different concentrations of $\mathrm{Y}^{3+}$ (Fig. 4). In the SEM-EDX analyses, solidified $Y$ was observed at the same location as $\mathrm{P}$ all over the cell surface (Fig. 5).

\section{Yttrium bioaccumulation by the Penicillium sp. ZD28}

Analysis of the accumulation of $\mathrm{Y}^{3+}$ by the fungus during microbial growth found that the accumulation of $\mathrm{Y}^{3+}$ per gram of dry cells was different under different concentrations of $\mathrm{Y}^{3+}$ (Table 2). Penicillium sp. ZD28 accumulated $54.89 \mu \mathrm{mol} / \mathrm{g}$ of $\mathrm{Y}^{3+}$ when the initial yttrium concentration was $73.71 \mu \mathrm{M}$, and the removal rate was $97 \%$. The fungus accumulated $199.07 \mu \mathrm{mol} / \mathrm{g}$ when the initial yttrium concentration was $461.57 \mu \mathrm{M}$, and the removal rate was $99 \%$. The content of $\mathrm{Y}^{3+}$ in the fungus reached a maximum of $411.32 \mu \mathrm{mol} / \mathrm{g}$ when the initial yttrium concentration was $580.67 \mu \mathrm{M}$, and the removal rate was $99 \%$.

The accumulation effect of fungus adsorbent on $\mathrm{Y}^{3+}$ was determined by spectrophotometry and the results are summarized in Table 3 . The accumulation content and removal rate of $\mathrm{Y}^{3+}$ by the active mycelium pellets 


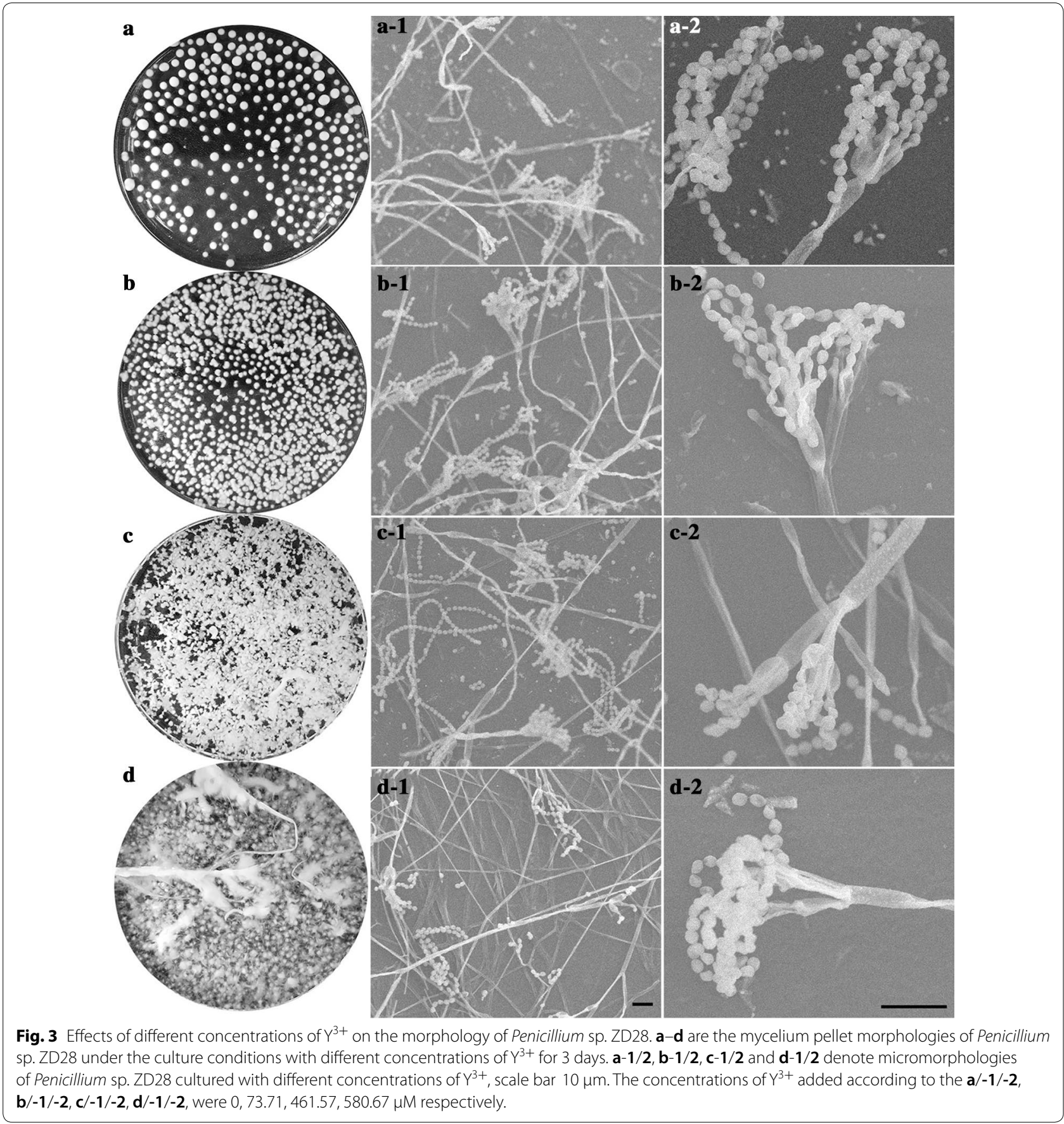

were both significantly lower than that those by the microbial powders. With increasing initial concentration of $\mathrm{Y}^{3+}$, the adsorption capacity and remove rate of $\mathrm{Y}^{3+}$ by the active mycelium pellets gradually decreased, and the adsorption capacity of $\mathrm{Y}^{3+}$ by the dry fungal powders increased gradually, whilst the removal rate decreased gradually.
The fungal powder adsorption of $\mathrm{Y}^{3+}$ from solution was described well by the linearized Freundlich adsorption isotherm equation:

$$
\log _{10}^{S}=\log _{10}^{K}+n \log _{10}^{C}
$$




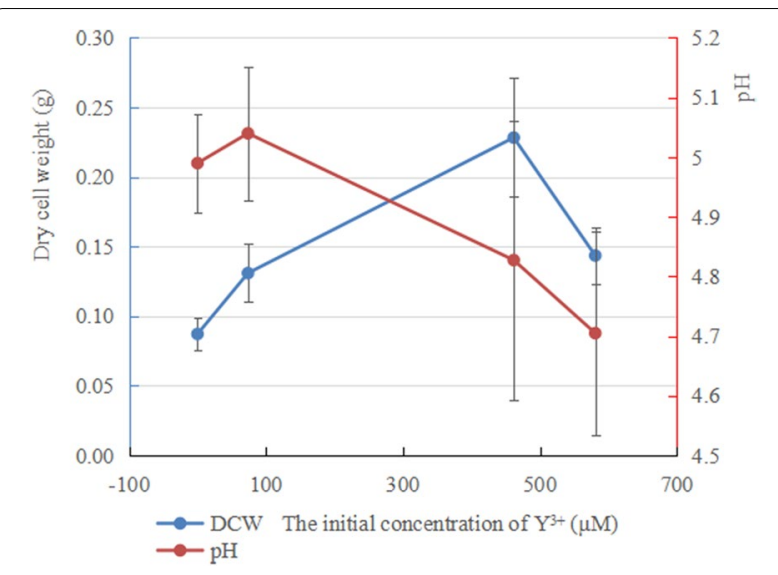

Fig. 4 The effect of different concentrations of $\mathrm{Y}^{3+}$ on the mycelium biomass and $\mathrm{pH}$ of cultures where $S$ is the amount of metal adsorbed in micromoles per gram, $C$ represents the equilibrium solution concentration in micromoles per liter, and $K$ and $n$ are the Freundlich constants. The constant $K$ represents the predicted quantity of metal removed in micromoles of metal per gram of dry cells at an equilibrium concentration of $1 \mu \mathrm{M}$. The simulation equation is as follows, $\mathrm{y}=0.1056 \mathrm{x}+2.5587, \mathrm{r}^{2}=0.9792$. The $\mathrm{Y}^{3+}$ content removed by Penicillium sp. ZD28 is $362 \mu \mathrm{mol} / \mathrm{g}$ at an equilibrium concentration of $1 \mu \mathrm{M}$.

\section{Discussion}

Ion-adsorption REEs are one of the most important rare earth mineral resources in China. There is a lack of new green technology of resource exploitation, which restricts development and utilization of ion-adsorption
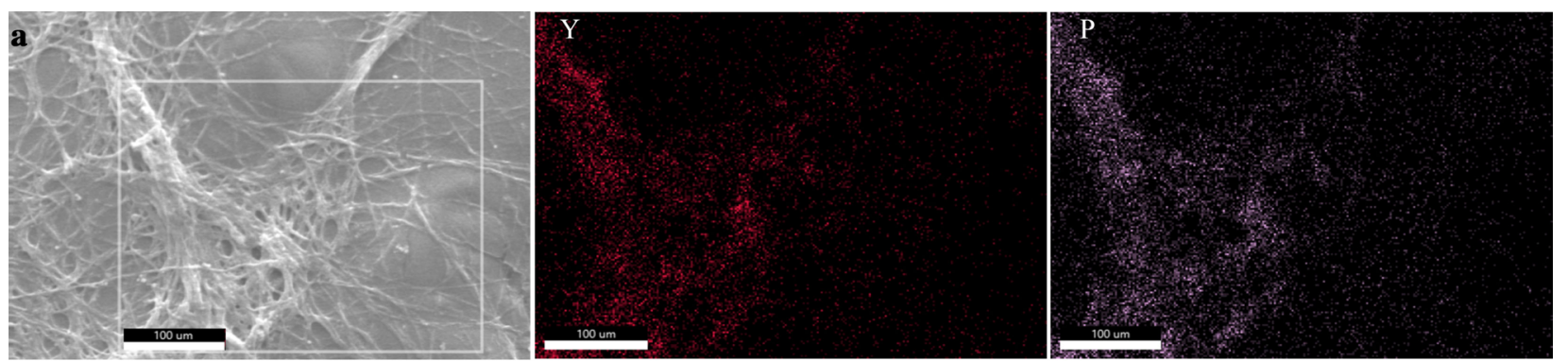

b

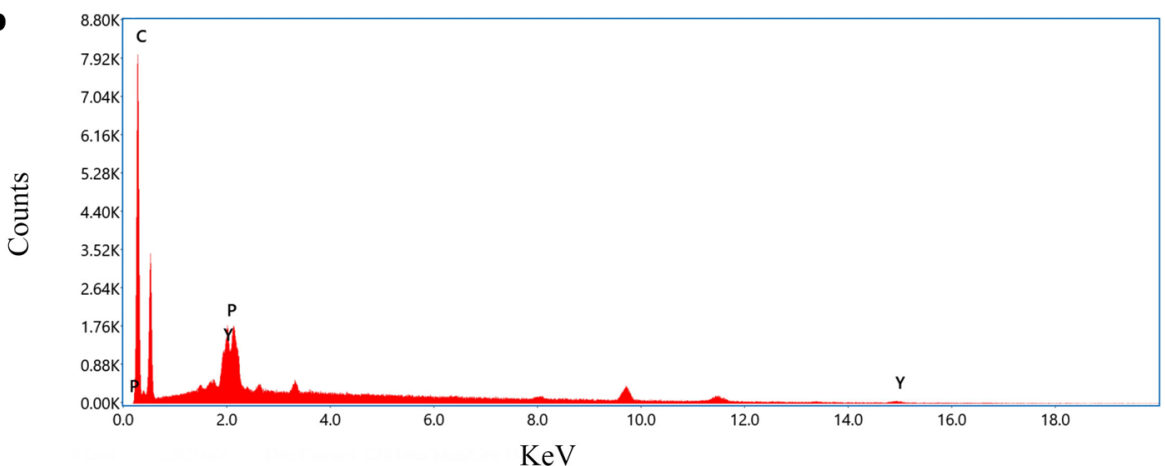

Fig. 5 SEM-EDX analyses of $Y$ in the ZD28 strain. a Back scattered electron image of the ZD28 strain after cultivation in the presence of $Y$ (left) and elemental maps of $Y($ red, middle) and $\mathrm{P}$ (pink, right). $\mathbf{b}$ Scans of the white rectangle box in $\mathbf{a}$

Table 2 Accumulation of $\mathrm{Y}^{3+}$ during the growth process of Penicillium sp. ZD28

\begin{tabular}{llccc}
\hline $\begin{array}{l}\text { The initial concentration } \\
\text { of } \boldsymbol{Y}^{\mathbf{3}+}(\boldsymbol{\mu} \mathbf{M})\end{array}$ & $\begin{array}{l}\text { Dry weight of the fungal } \\
\text { biomass }(\mathbf{g})\end{array}$ & $\begin{array}{l}\text { The residual concentration } \\
\text { of } \boldsymbol{Y}^{\mathbf{3 +}}(\boldsymbol{\mu} \mathbf{M})\end{array}$ & $\begin{array}{l}\text { The accumulation concentration } \\
\text { of } \mathbf{Y}^{\mathbf{3 +}}(\boldsymbol{\mu m o l} / \mathbf{g})\end{array}$ & $\begin{array}{l}\text { Removal } \\
\text { rate }(\%)\end{array}$ \\
\hline $73.71( \pm 10.02)$ & $0.13( \pm 0.02)$ & $2.35( \pm 1.27)$ & 54.89 & 97 \\
$461.57( \pm 23.29)$ & $0.23( \pm 0.04)$ & $3.70( \pm 0.57)$ & 199.07 & 99 \\
$580.67( \pm 34.51)$ & $0.14( \pm 0.02)$ & $4.82( \pm 0.59)$ & 411.32 & 99 \\
\hline
\end{tabular}


Table 3 Adsorption of $\mathrm{Y}^{3+}$ by the mycilium pellets and the dry fungal powder

\begin{tabular}{|c|c|c|c|c|c|c|}
\hline \multirow[t]{2}{*}{$C_{0}(\mu \mathrm{M})$} & \multicolumn{3}{|c|}{ The mycelium pellets } & \multicolumn{3}{|l|}{ The fungal powder } \\
\hline & $\mathrm{Ce}(\mu \mathrm{M})$ & $\mathrm{S}(\mu \mathrm{mol} / \mathrm{g})$ & $\begin{array}{l}\text { Removal rate } \\
\text { (\%) }\end{array}$ & $\mathrm{Ce}(\mu \mathrm{M})$ & $\mathrm{S}(\mu \mathrm{mol} / \mathrm{g})$ & $\begin{array}{l}\text { Remova } \\
\text { rate (\%) }\end{array}$ \\
\hline $465.19( \pm 70.57)$ & $386.25( \pm 67.44)$ & 78.94 & 17 & $10.01( \pm 10.43)$ & 455.18 & 98 \\
\hline $1052.21( \pm 78.07)$ & $978.66( \pm 57.04)$ & 73.55 & 7 & $352.01( \pm 30.40)$ & 700.20 & 67 \\
\hline $4804.36( \pm 91.90)$ & $4675.50( \pm 88.30)$ & 58.87 & 1 & $3983.81( \pm 54.90)$ & 821.55 & 17 \\
\hline $6382.63( \pm 134.88)$ & $6360.56( \pm 156.61)$ & 22.08 & 0.3 & $5455.48( \pm 104.32)$ & 927.15 & 15 \\
\hline
\end{tabular}

rare earth resources to some extent. Several studies have reported on microbial adsorption (accumulation) of rare-earth ions, however, most of studies focused on light and medium rare earths such as lanthanum, europium, samarium and dysprosium (Ozaki et al. 2015; Tsuruta 2006; Texier et al. 1999) whilst few have reported on heavy rare earths. Middle and heavy rare earth deposits in southern China account for two-thirds of the total reserves of rare earth deposits in China. In particular, the "Foot Cave" deposits in the south of Jiangxi province is yttrium-rich and yttrium accounts for more than $90 \%$ of the total rare earth content. Analysis of REE content in soil samples supported that "Foot Cave" as an yttriumrich ion-adsorption type rare earth deposit. REEs in the granite parent rock are very low-grade. With the weathering of the minerals, the REEs migrate upwards and absorb onto the surface of clay minerals in the form of ions. Therefore, this study on the interactions between yttrium ion and fungus, which originated from the "Foot Cave", is of great theoretical value and practical significance in the application of fungal adsorption of rare earth ions.

There have been many reports on the adsorption of rare earth ions by microbial powders. For example, the adsorption of rare earth lanthanum ions $\left(\mathrm{La}^{3+}\right)$ by various bacteria (Bacillus cereus, B. subtilis, Escherichia coli and P. aeruginosa) was tested. The results showed that bacterial adsorption of $\mathrm{La}^{3+}$ conforms to the Freundlich model, and an average of $27 \%$ of the total $\mathrm{La}^{3+}$ was adsorbed from $1 \mathrm{mM}$ solutions. Precipitates composed of lanthanum are crystalline, needlelike deposits that formed around the $P$. aeruginosa cells (Mullen et al. 1989). Seventy-six strains including bacteria, actinomycetes, fungi and yeast were used to adsorb the rare-earth element $\mathrm{Sm}$. The results indicated that gram-positive bacteria exhibited a particularly high capacity for accumulation of Sm. In particular, B. licheniformis cells accumulated approximately $316 \mu \mathrm{mol} \mathrm{Sm}$ per gram dry wt. of microbial cells (Tsuruta 2007). However, there are very few reports on adsorption of yttrium group rare-earth ions by fungi, especially during the growth of microorganism. Tolerance has to be considered when we do the researches about microbial accumulation for yttrium ions during the growth process of fungi. When exposed to high concentration of $\mathrm{Y}^{3+}$, microorganism with good tolerance can be survival, growth and then adsorption even absorption. Therefore, the strain number 1 with the largest tolerance to $\mathrm{Y}^{3+}$ was designated as the target fungus. Luckily, the adsorption capacity for $\mathrm{Y}^{3+}$ was significant during the growth of Penicillium sp. ZD28, where the removal rate was around $99 \%$ when the initial concentration of $\mathrm{Y}^{3+}$ was less than $0.6 \mathrm{mM}$. Of course, there may be no direct correlation between tolerance and adsorption capacity, as reported by d'Aquino. He found that REE accumulation in Trichoderma harzianum T22 is lower than that in T. atroviride P1, although T22 has better tolerance. He also found that growth stimulation by REE and REE accumulation in fungal biomass are not directly related to each other (d' Aquino et al. 2009). It is complicated that the relation between growth stimulation, fungal tolerance to REE and REE accumulation in fungal biomass.

In this study, the fungal powder from Penicillium sp. ZD28 showed good adsorption performance for $\mathrm{Y}^{3+}$. The adsorption capacity for $\mathrm{Y}^{3+}$ was greater than $455 \mu \mathrm{mol} / \mathrm{g}$ under initial concentrations of $0.4,1.0,4.8$ and $6.4 \mathrm{mM}$, and higher than the previously reported microbial adsorption capacity of rare earth ions. These findings indicate that the fungal powder has great potential in ion adsorption of yttrium group rare earth. Also, low concentration yttrium can increase fungal biomass, whilst high concentrations can inhibit the growth and the number of spores (Fig. 1). Under liquid culture conditions, the mycelium exhibited a diffuse feathery appearance with increasing the concentration of $\mathrm{Y}^{3+}$, not due to the decrease in $\mathrm{pH}$ caused by the addition of $\mathrm{Y}^{3+}$ (Fig. 4), really because yttrium ions adsorbed on the surface of mycelium (Fig. 5) or entered the cell to inhibit the extension of mycelium. However, no obvious effect on the micromorphology of mycelium and spores was observed (Fig. 3).

Investigations into the accumulation of $\mathrm{Y}^{3+}$ by fungus in three physiological states (growth process, the mycelial pellets with physiological activity and the fungus 
powder after being ground) were conducted. Results showed that the prepared mycelium pellets (about $1 \mathrm{~mm}$ in diameter) had a poor ability to accumulate $\mathrm{Y}^{3+}$ having a significantly lower adsorption capacity and removal rate of $\mathrm{Y}^{3+}$ than the fungal dry powders and the growing process of Penicillium sp. ZD28. Moreover, the adsorption quantity by the mycelium pellets was reduced with increasing $\mathrm{Y}^{3+}$, showing that high concentrations of yttrium are toxic to cells. At high concentrations of yttrium ions $(>0.6 \mathrm{mM})$, adsorption during the growth of the fungus was not suitable because the ions can easily precipitate with components of the medium. Therefore, when Penicillium sp. ZD28 was used for $\mathrm{Y}^{3+}$ adsorption, the high concentration was suitable when using the fungal powder, whilst the low concentration was suitable for adsorption by the growing fungus. In this study, the adsorption of $\mathrm{Y}^{3+}$ by the fungal powder was well fitted by the Freundlich, where $R^{2}$ was equal to 0.9792 . And values of $\mathrm{n}$ were substantially smaller than 1 suggesting more heterogeneous adsorption sites on the adsorbents (Ahmed et al. 2015). The smaller the $n$, the higher the affinity of the absorbent to the ions (Ji et al. 2010). The $n$ in our work was equal to 0.1056, smaller than those of metal ions adsoption by various biological and non-biological materials (Chen et al. 2019; Wei et al. 2019; Mullen et al. 1989). Therefore, Penicillium sp. ZD28 has significant potential in the environmental recovery of yttrium ions.

\section{Abbreviations}

ICP-MS/MS: inductively coupled plasma tandem mass spectrometry; REEs: rare earth elements.

\section{Acknowledgements}

Not applicable.

\section{Authors' contributions}

$W Y$ and $Z D$ designed the experiments, $W Y, C L$ and $Y Q$ executed the experiments. WY, ZB and RM analyzed experiments results. WY wrote and revised the manuscript. All authors read and approved the final manuscript.

\section{Funding}

This work was supported by Youth Science and Technology Foundation of Jiangxi, China (20192BAB214002), Research project of education department of Jiangxi, China (No. GJJ8831), Open fund from Key Laboratory of Protection and Utilization of Subtropical Plant Resources of Jiangxi (YRD201907).

\section{Availability of data and materials}

The data supporting our finding included in the manuscript. Please turn to the corresponding author for all other requests.

\section{Ethics approval and consent to participate}

This article does not contain any studies with human participants or animals performed by any of the authors.

\section{Consent for publication}

Not applicable.

\section{Competing interests}

The authors declare that they have no competing interests.

\section{Author details}

${ }^{1}$ Key Laboratory of Protection and Utilization of Subtropical Plant Resources of Jiangxi Province, College of Life Sciences, Jiangxi Normal University, Nanchang 330022, China. ${ }^{2}$ Key Laboratory of Bioprocess Engineering of Jiangxi Province, College of Life Sciences, Jiangxi Science and Technology Normal University, Nanchang 330013, China.

Received: 4 December 2019 Accepted: 18 January 2020

Published online: 03 February 2020

\section{References}

Ahmed MB, Zhou JL, Ngo HH, Guo WS (2015) Adsorptive removal of antibiotics from water and wastewater: progress and challenges. Sci Total Environ 532:112-126

Alonso E, Sherman AM, Wallington TJ, Everson MP, Field FR, Roth R, Kirchain RE (2012) Evaluating rare earth element availability: a case with revolutionary demand from clean technologies. Environ Sci Technol 46(6):34063614. https://doi.org/10.1021/es3011354

Altschul SF, Gish W, Miller W, Myers EW, Lipman DJ (1990) Basic local alignment search tool. J Mol Biol 215:403-410. https://doi.org/10.1016/\$0022 $-2836(05) 80360-2$

Brierley CL, Brierley JA (2013) Progress in bioleaching: part B: applications of microbial processes by the minerals industries. Appl Microbiol Biotechnol 97:7543-7552

Chen XP, Feng XJ, Sun F (2013) Effect of yttrium on activity of microbes in soil. Chin Environ Sci Technol 8: 41-44. http://qikan.cqvip.com/Qikan/Article/ Detail?id=46968690\&from=Qikan_Search_Index

Chen HY, Li WY, Wang JJ, Xu HJ, Liu YL, Zhang Z, Li YT, Zhang YL (2019) Adsorption of cadmium and lead ions by phosphoric acid-modified biochar generated from chicken feather: selective adsorption and influence of dissolved organic matter. Bioresour Technol 292:121948

d'Aquino L, Morgana M, Carboni MA, Staiano M, Antisari MV, Re M, Lorito M, Vinale F, Abadi KM, Woo SL (2009) Effect of some rare earth elements on the growth and lanthanide accumulation in different trichoderma strains. Soil Biol Biochem 41(12):2406-2413

Das N (2010) Recovery of precious metals through biosorption-a review. Hydrometallurgy 103(1):180-189

Felsenstein J (1985) Confifidence limits on phylogenies: an approach using the bootstrap. Evolution 39:783-791. https://doi.org/10.2307/2408678

Feng AJ, Xiao X, Ye CC, Xu XM, Zhu Q, Yuan JP, Hong YH, Wang JH (2017) Isolation and characterization of Burkholderia fungorum Gan-35 with the outstanding ammonia nitrogen-degrading ability from the tailings of rare-earth-element mines in southern Jiangxi, China. AMB Expr 7(1): 140. https://amb-express.springeropen.com/track/pdf/10.1186/s1356 8-017-0434-x

Gang GH, Cho HJ, Kim HS, Kwack YB, Kwak YS (2015) Analysis of fungicide sensitivity and genetic diversity among Colletotrichum species in sweet persimmon. Plant Pathol J 31 (2): 115-122. http://koreascience.or.kr/artic le/JAKO201517058945214.page

Gao ZQ, Zhou QX (2011) Contamination from rare earth ore strip mining and its impacts on resources and eco-environment. Chin J Ecol 30 (12): 2915-2922. http://qikan.cqvip.com/Qikan/Article/Detail?id=40165 515\&from=Qikan_Search_Index

Hogendoorn C, Roszczenkojasińska P, Martinezgomez NC, Graaff J, Grassl P, Pol A, Op den Camp H, Daumann L (2018) Facile arsenazo iii-based assay for monitoring rare earth element depletion from cultivation media for methanotrophic and methylotrophic bacteria. Appl Environ Microbiol 84 (8): e02887-17. https://aem.asm.org/content/84/8/e02887-17

Horiike T, Yamashita M (2015) A new fungal isolate, Penidiella sp. strain T9, accumulates the rare earth element dysprosium. Appl Environ Microbiol 81: 3062-3068. https://aem.asm.org/content/81/9/3062

Ji LL, ShaoY XuZY, Zheng SR, Zhu DQ (2010) Adsorption of monoaromatic compounds and pharmaceutical antibiotics on carbon nanotubes activated by $\mathrm{KOH}$ etching. Environ Sci Technol 44(16):6429-6436. https:// doi.org/10.1021/es1014828

Kücüker MA, Nadal JB, Kuchta K (2016) Comparison between batch and continuous reactor systems for biosorption of neodymium (Nd) using microalgae. Int J Plant Anim Environ Sci 6: 197-203. http://www.ijpaes.com/ 
Li PS, Tao HC (2015) Cell surface engineering of microorganisms towards adsorption of heavy metals. Crit Rev Microbiol 41(2): 140-149. https:// www.tandfonline.com/doi/abs/10.3109/1040841X.2013.813898?journ alCode=imby20

Marmur J (1961) A procedure for the isolation of deoxyribonucleic acid from microorganisms. J Mol Biol 3:208-218

Moldoveanu GA, Papangelakis Vladimiros G (2012) Recovery of rare earth elements adsorbed on clay minerals: I. Desorption mechanism. Hydrometallurgy 117:71-78

Moriwaki H, Yamamoto H (2013) Interactions of microorganisms with rare earth ions and their utilization for separation and environmental technology. Appl Microbiol Biotechnol 97(1):1-8

Mullen MD, Wolf DC. Ferris FG, Beveridge TJ, Flemming CA, Bailey GW (1989) Bacterial sorption of heavy metals. Appl Environ Microbiol 55 (12): 3143-3149. https://aem.asm.org/content/55/12/3143

Ozaki T, Kimura T, Ohnuki T, Francis AJ (2015) Associations of Eu (ш) with gram-negative bacteria, Alcaligenes faecalis, Shewanella putrefaciens, and Paracoccus denitrificans. J Nucl Radiochem Sci 6(1):73-76. https://doi. org/10.14494/jnrs2000.6.73

Saitou N, Nei M (1987) The neighbor-joining method: a new method for reconstructing phylogenetic trees. Mol Biol Evol 4: 406-425. https://academic. oup.com/mbe/article/4/4/406/1029664

Stone, R (2009) As China's rare earth R\&D becomes ever more rarefied, others tremble. Science 325 (5946): 1336-1337. https://science.sciencemag.org/ content/325/5946/1336

Tamura K, Nei M, Kumar S (2004) Prospects for inferring very large phylogenies by using the neighbor-joining method. Proc Natl Acad Sci USA 101:11030-11035. https://doi.org/10.1073/pnas.0404206101

Tamura K, Peterson D, Peterson N, Stecher G, Nei M, Kumar S (2011) MEGA5: molecular evolutionary genetics analysis using maximum likelihood, evolutionary distance, and maximum parsimony methods. Mol Biol Evol 28:2731-2739. https://doi.org/10.1093/molbev/msr121
Texier AC, Yves Andrès A, Cloirec PL (1999) Selective biosorption of lanthanide (La, Eu, Yb) ions by Pseudomonas aeruginosa. Environ Sci Technol 33(33):489-495. https://doi.org/10.1021/es9807744

Tsuruta T (2006) Selective accumulation of light or heavy rare earth elements using gram-positive bacteria. Colloids Surf B 52(2):117-122

Tsuruta T (2007) Accumulation of rare earth elements in various microorganisms. J Rare Earth 25(5):526-532

US Department of Energy (2011) Critical materials strategy. http://energy.gov/ sites/prod/files/DOE_CMS2011_FINAL_Full.pdf

Wang ZC (2014) Export issues of China's rare earth resources and its countermeasure analysis. Master degree paper of Jilin university. http://cdmd. cnki.com.cn/Article/CDMD-10183-1014211790.htm

Wei LL, Li JJ, Xue M, Wang S, Li QY, Qin K, Jiang JQ, Ding J, Zhao QL (2019) Adsorption behaviors of $\mathrm{Cu}^{2+}, \mathrm{Zn}^{2+}$ and $\mathrm{Cd}^{2+}$ onto proteins, humic acid, and polysaccharides extracted from sludge EPS: sorption properties and mechanisms. Bioresour Technol 291:121868

Xiao YF, Huang XW, Feng ZY, Dong JS, Huang L, Long ZQ (2015) Progress in the green extraction technology for rare earth from ion-adsorption type rare earths ore. Chinese Rare Earths 3:109-115. http://chinasciencejournal. com/index.php/XT/article/view/1822285

Yang GM (2015) Mineral geology of China, dossier of Jiangxi. Geology Press, Beijing, p 2015

Zhuang WQ, Fitts JP, Ajo-Franklin CM, Maes S, Alvarez-Cohen L, Hennebel T (2015) Recovery of critical metals using biometallurgy. Curr Opin Biotechnol 33:327-335

\section{Publisher's Note}

Springer Nature remains neutral with regard to jurisdictional claims in published maps and institutional affiliations.

\section{Submit your manuscript to a SpringerOpen ${ }^{\circ}$ journal and benefit from:}

- Convenient online submission

- Rigorous peer review

- Open access: articles freely available online

- High visibility within the field

- Retaining the copyright to your article

Submit your next manuscript at $\boldsymbol{\nabla}$ springeropen.com 